\title{
深度方向に強度が増加する地盤中の根入れ基礎 の鉛直支持力の模型実験と解析
}

\author{
北誥 昌樹 ${ }^{1} \cdot$ 中村 健 $^{2}$ \\ ${ }^{1}$ 正会員 工博 港湾空港技術研究所 地盤·構造部 地盤改良研究室長 (T239-0826 横須賀市長瀬 3-1-1) \\ ${ }^{2}$ 港湾空港技術研究所 地盤·構造部 地盤改良研究室 (广239-0826 横須賀市長瀬 3-1-1)
}

\begin{abstract}
深度方向に強度が増加する地盤の鈆直支持力を実験と特性曲線法による数值解析より検討した. 遠心模型実 験は基礎幅, 根入れ深さを種々に変化させた条件で行った. 実験の結果, 極限支持力は根入れ基礎幅比とともに 直線的に增加すること, 極限支持力発現後の鈶直荷重と基礎底面の深さとの関係は載荷前の根入れ深さと関係 なく1本の線上にのることが確認された. 一方, 数值解析で得た基礎底面での支持力係数は基礎幅 $B$, 地盤のせ ん断強度 $C_{D f}$ とその深度方向增加率 $k$ による指標 $k B / C_{D f}$ が大きいほど大きく, 根入れの影響は根入れ分の自重 応力に相当することが分かった. 支持力の計算値と実験值は近い值を示し, 基礎底面での反力分布も実験と計算 がほほ一致することが確認された.
\end{abstract}

Key Words: bearing capacity, centrifuge model test, clay, numerical analysis, vertical load

\section{1.はじめに}

港湾施設や海上空港などの建設予定地には, 軟弱 な粘土層が厚く堆積している場合が多く, その地盤強 度分布は一般に深度方向にほぼ一定割合で大きくなっ ている. その際, 支持力の確保や沈下の抑制のために 地盤改良が行われる場合が多く, 深層混合処理工法も 多く用いられている.

改良地盤にはケーソンなどの上部構造物の重量や埋 立層からの土圧などが作用する. 深層混合処理工法に よる改良土は, 原地盤の土と比べて一般に強度および 変形係数が著しく大きく, 破壊時のひずみ量は著しく小 さいことが確認されている. そのため, ブロック式の深層 混合処理地盤の設計にあたっては, 改良地盤を一種の 構造物と見なして, 重量や外力に対する改良地盤全体 の安定 (外部安定) と, 改良地盤自体の耐力 (内部安 定）と改良地盤の変位を検討することとしている ${ }^{1), 2)}$. 外 部安定の検討では, 滑動破壊, 転倒破壊と支持力破壊 の3つの破壊モードを仮定し, 個別に検討している.

一方, 改良地盤の深さと幅の比率は一般的には 1 以 下であるため, 根入れのある浅い基礎と考えることもで きる.このように改良地盤を考えると, 外部安定の検討 は偏心傾斜荷重下での支持力の検討に集約できるの ではないかと考えられる.

このような背景の下, 筆者らは粘土地盤中の根入れ のある浅い基礎の偏心傾斜荷重下の支持力に関する 研究を進めている. 本報告では, 一連の研究の一環と
して行った, 根入れのある基礎の鈶直支持力について の遠心模型実験ならびに特性曲線法による解析結果 について報告する.

\section{2. 鉛直支持力解析に関する既往の研究}

支持力の解析に関して, 最近 Kusakabe and Lee ${ }^{3)}$ が Terzaghi に始まる古典的理論から最近の信頼性設計に 至る研究の流れを概観している. その中で Solution table として, 基礎の形状別に荷重の作用方向, 地盤の 条件, 地盤の総数等のパラメー夕毎に研究実績の有無 を一覧表で示している.これにより本論文で取り上げる 帯基礎の鈶直支持力については, 深さ方向の強度增 加, 応力依存性, 異方性, 二層地盤といった条件下で 解析がなされていると述べられている.

深さ方向に強度が増加する地盤の支持力について 解析, 実験を行った既往の研究としては, まず Davis and Booker $\left.{ }^{4}\right)$ による解析があげられる. 彼らは, 粘土地 盤上の表面基礎を対象とした特性曲線法による支持力 計算を行い, 強度分布の鉛直支持力への影響を求め ている. その中で, 粘土地盤表面でのせん断強度 $C_{0}$, 深度方向のせん断強度の增加率 $k$, 基礎幅 $B$ を組み合 わせた指標 $k B / C_{0}$ (または $C_{0} / k B$ ) 導入し, 鉛直支持 カへの影響倸数 $(F s)$ を求めている.

木村と竹村 ${ }^{5)}$ は, 前述の Davis and Booker の研究成 果を踏まえ, 深さ方向に強度が増加する粘土地盤上の 
表-1 カオリン粘土の物性

\begin{tabular}{|c|c|c|}
\hline \multicolumn{2}{|c|}{$\begin{array}{c}\text { 土粒子の密度 } \\
\left(\mathrm{g} / \mathrm{cm}^{3}\right)\end{array}$} & 2.638 \\
\hline \multicolumn{2}{|c|}{ 液性限界(\%) } & 63.8 \\
\hline \multicolumn{2}{|c|}{ 塑性限界 (\%) } & 26.8 \\
\hline \multicolumn{2}{|c|}{ 塑性指数 } & 37.0 \\
\hline \multicolumn{2}{|c|}{ 分類名(分類記号) } & 粘土(CH) \\
\hline \multirow{3}{*}{$\begin{array}{l}\text { 粒度 } \\
\text { 分布 } \\
(\%)\end{array}$} & 砂分 & 1 \\
\hline & シルト分 & 22 \\
\hline & 粘土分 & 77 \\
\hline \multicolumn{2}{|c|}{ 最大粒径 $(\mathrm{mm})$} & 0.425 \\
\hline
\end{tabular}

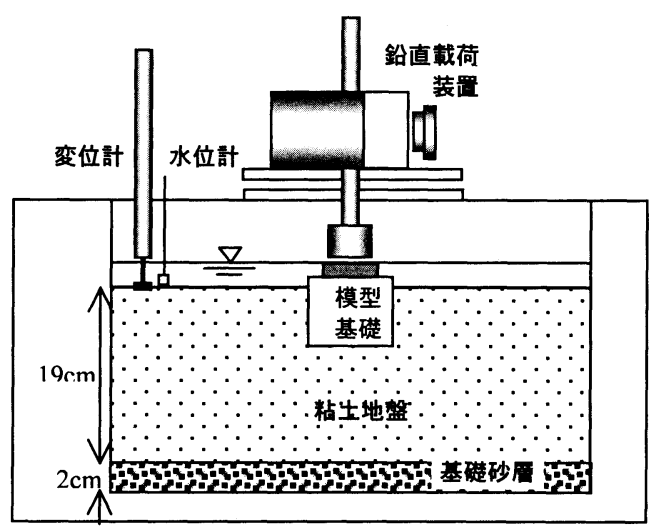

図-1 模型地盤セットアップ図(B7D7-10)

表面基礎の鈶直支持力を上界值計算により算出してい る. さらに彼らは, 遠心模型実験も実施して数值計算と 比較し,両者はほぼ一致したと述べている.

一方, 粘土地盤中の根入れ基礎の支持力に関して, Tani and Craig ${ }^{6}$ は, 海底油田の油井の基礎を念頭に 特性曲線法による支持力計算を行い, 地盤表面の帯基 礎の支持力係数, 円形基礎の形状係数, 根入れ係数 を求め, 深度方向に強度が增加する地盤中の根入れ のある基礎の鉛直支持力の算定式を提案している. さら に, 彼らは比較的根入れ深さの小さい条件についてい くつかの遠心模型実験を行い, 計算值が実験結果とほ ぼ一致したことを示している. 最近では, Martin ${ }^{7}$ は根 入れのある円形基礎を対象に支持力解析を行い, 上 界・下界值計算により得られた結果を図表化している.

実験を中心とした研究事例としては, 西村ほか ${ }^{8)}$ と飯 島ほか 9)が中間土の地盤に対して根入れ基礎の鈶直 載荷試験を遠心場で行っている. 彼らは, 実験から求 められた支持力係数は, 根入れ基礎幅比の增加に伴 い大きくなるが, 上界值計算の結果とはあまり合わなか つたと報告している.

このように根入れのある支持力に関してはいくつかの 実験的・解析的研究があるが, 深さ方向に強度增加す る地盤で, 根入れ深さが 1 程度の帯基礎の支持力につ

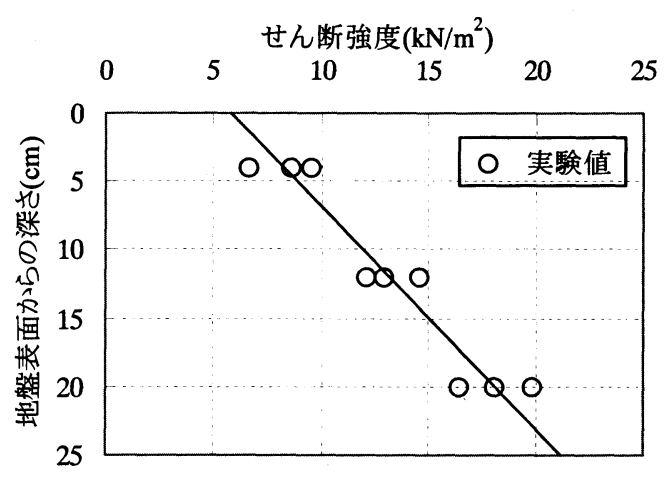

図-2 地盤強度分布

表-2 実験一覧

\begin{tabular}{|c|c|c|c|c|c|c|}
\hline \multirow[b]{2}{*}{$\begin{array}{c}\text { ケース } \\
\text { 名 }\end{array}$} & \multirow{2}{*}{\begin{tabular}{|c} 
根入れ \\
深さ \\
$D_{f}(\mathrm{~cm})$ \\
\end{tabular}} & \multirow{2}{*}{$\begin{array}{l}\text { 基礎 } \\
\text { 幅 } B \\
\text { (cm) }\end{array}$} & \multirow[b]{2}{*}{$\frac{D_{f}}{B}$} & \multirow[b]{2}{*}{$\frac{k B}{C_{D f}}$} & \multicolumn{2}{|c|}{ 支持力値 } \\
\hline & & & & & $\begin{array}{c}\text { 压力 } \\
\left(\mathrm{kN} / \mathrm{m}^{2}\right)\end{array}$ & $N_{c}$ \\
\hline B5D0 & 0 & 5 & 0 & 0.53 & 29.7 & 5.13 \\
\hline B5D5 & 5 & 5 & 1 & 0.35 & 63.0 & 6.83 \\
\hline B5D10 & 10 & 5 & 2 & 0.26 & 105.2 & 7.62 \\
\hline B7D7-10 & 7 & 7 & 1 & 0.43 & 110.8 & 8.83 \\
\hline B7D7-12 & 7 & 7 & 1 & 0.43 & 112.6 & 9.00 \\
\hline B10D0 & 0 & 10 & 0 & 1.07 & 34.5 & 5.97 \\
\hline
\end{tabular}

いては未だ十分に検討されているとは言い難い. そこで, 本研究では深度方向に強度增加する粘土地盤中の根 入れ帯基礎の支持力について遠心模型実験之特性曲 線法による数値解析で検討した.

\section{3. 遠心模型実験}

\section{（1）実験方法及び実験ヶース}

遠心模型実験で用いた粘土はカオリン粘土で, その 物性は表-1 に示すとおりである. 図一1 はセットアップさ れた模型地盤の概要を示している. 模型地盤の作製は, まず試料容器内に排水層である砂層を作製した後, 含 水比を $120 \%$ に調整したカオリン粘土スラリーを投入し た. その後粘土表面に $83 \mathrm{kN} / \mathrm{m}^{2}$ の圧力を作用させ地盤 を圧密した. なお, 根入れのある基礎の実験の場合は, 最終圧密圧力の $3 / 4$ 程度の圧力で圧密し, その後一旦 圧力を開放して基礎の根入れ分の粘土を除去してべー クライト製の模型基礎を設置した. その後, 最終圧密圧 力である $83 \mathrm{kN} / \mathrm{m}^{2}$ で再度圧密させた.

深首混合処理による改良地盤は原地盤に固化材を 靚汼混合して作製するため, 改良地盤と原地盤の境界 は粗な条件と考えられる. そのため, 遠心模型実験や 


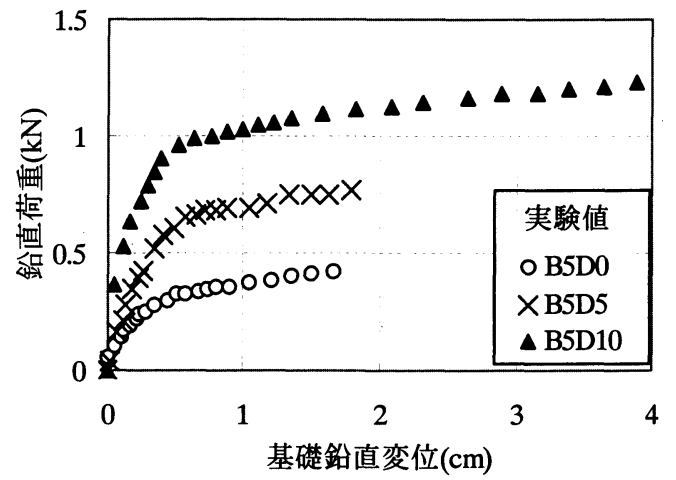

(a) 基硒幅 $5 \mathrm{~cm}$

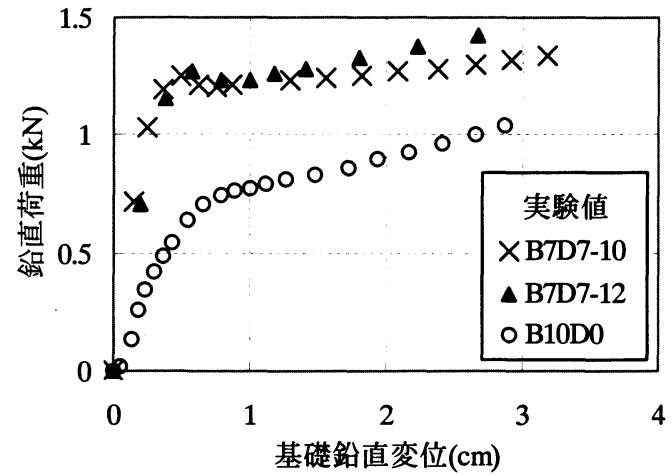

(b) 基礎幅 $7 \mathrm{~cm}, 10 \mathrm{~cm}$

図-3 荷重～基整鈶直変位関保

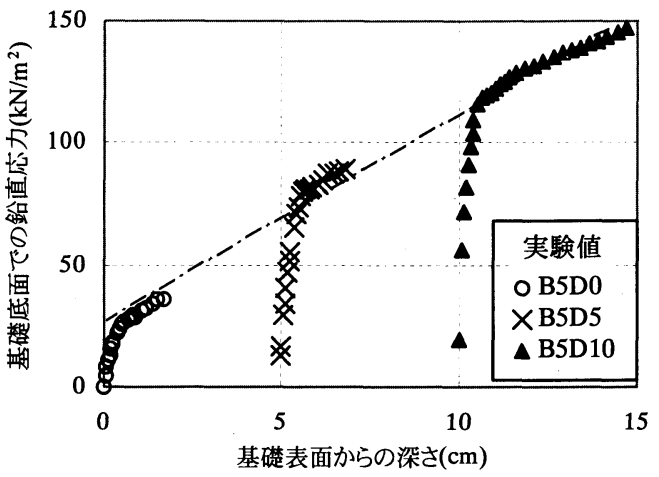

図-4 鈶直応力 基礎深さ

解析などでは, 基礎周面を粗な条件とした研究を行う必 要性が高い. しかし模型実験で周面が粗な条件の基礎 の模型地盤を作製するためには, 地盤作製上いくつか の問題があった. そのため, ここでは研究の第一段階と して周面が滑な条件での検討を行った. 実験では, 模 型基礎の周面が滑な条件とするために, 模型基礎表面 にシリコン潤滑剤を塗布して可能な限り付着を除去する ように努めた。

実験室内で作製された模型地盤を遠心模型実験装 置に搭載し, $50 \mathrm{~g}$ の遠心加速度の下で自重圧密させた. 自重圧密中には粘土地表面の沈下ならびに粘土地盤 中の間隙水圧を計測して, 90\%以上の圧密に達したこ とを確認した. 自重圧密終了後, 試料容器に取り付けた 鈆直載荷装置により模型基礎を一定速度で沈下させ, 変位制御で鈶直載荷を行った. 載荷速度は非排水条 件を満足させるために $23 \mathrm{~mm} /$ 分と速く設定した. 実験は 表-2 に示すように, 基礎幅と根入れ基礎幅比を変化さ せ, 5 種類の $k B / C_{D f}$ (根入れ深さ $D_{f}$ である基礎底面での せん断強度という意味で $C_{D f}$ と表記する)条件で合計 7ケース行った. ケース名が B7D7の場合のみ-10,-12 サフィックスがついているのは, 同じ基礎幅, 根入れ深 さでの実験を偏心傾斜荷重の実験も含めて多数行った ためで, そのうち鈶直載荷試験を行ったケースのみ掲

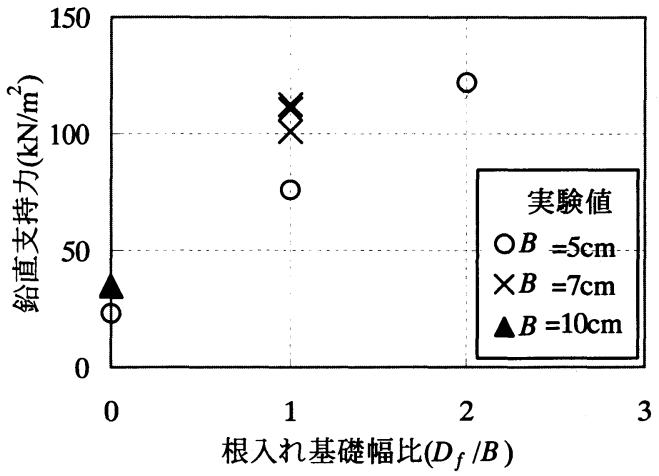

图-5 鈶直支持力 $D_{f} / B$

げた.

粘土地盤の非排水せん断強度分布は, 載荷実験と 同じ材料, 手順で別途作製した粘土地盤について $50 \mathrm{~g}$ の遠心場でベーン試験を行って求めた. カオリン粘土 地盤の非排水せん断強度が, 遠心場でのベーン試験 で精度良く求められることは北詰らの研究により確認さ れている ${ }^{10)}$. なお, 地盤強度の測定のための実験は 3 ケース行った. 図-2 は得られた地盤の非排水せん断深 度方向の強度分布である. 図より地盤が，地表面での 強度を有し深度方向に直線的に増加する地盤が形成 されていることが分かる.

\section{（2）実験結果及び考察}

\section{a）鉛直荷重と鉛直変位の関係}

実験で得られた鈶直荷重と基礎の鈶直変位の関係を 図-3に示した. 図-3(a)は基礎幅が $5 \mathrm{~cm}$ で根入れの異 なる場合を, 図-3(b)は基礎幅が $7 \mathrm{~cm}$ と $10 \mathrm{~cm}$ の場合を それぞれまとめて示している. まず, 基礎幅が $5 \mathrm{~cm}$ の場 合について見ると(図-3(a))，いずれのケースも基礎の 鉿直変位に伴い鈶直荷重が急速に増加し, その後荷 重は基礎の沈下に伴い徐々に增加する傾向が見られ る. 同様の傾向は基礎幅が $7 \mathrm{~cm}, 10 \mathrm{~cm}$ の場合にも見ら れる(図-3(b)参照)。基礎幅が $5 \mathrm{~cm}$ の場合について載 


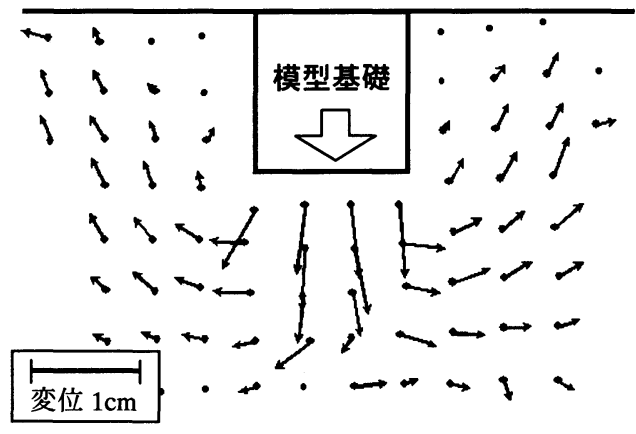

図6 地盤の変形挙動(B7D7-10)

荷初期の荷重増加割合を見ると,根入れの大きいケース の方が荷重増加割合が大きい傾向が見られる.これは 粘土地盤が深度方向に強度が增加するため, 根入れが 深いほど基礎底面位置での地盤強度が大きくなるため と考えられる.

図-3(a)で示した基礎幅 $5 \mathrm{~cm}$ の実験ケースの荷重〜 基礎鈶直変位関係について, 載荷中の地盤表面から 基礎底面までの深さを横軸に, 基礎底面での鉛直応力 を縦軸として示したのが図-4 である. なお, 図中の鉛直 応力は, 載荷装置による鉛直圧力と基礎自重による圧 力の合計である. この図より, 同じ幅の基礎の場合, 載 荷後半部で漸增する部分の鈶直応力と基礎深さの関 係は, 図に一点鎖線で示した1本の線上に乗っているこ とが分かる. 同様の傾向は砂地盤を対象とした研究 ${ }^{11)}$ でも見られている.

\section{b）極限支持力と根入れ基礎幅比の関係}

地盤の極限支持力を, 荷重〜沈下曲線に明瞭なピ 一クが見られる B7D7-2, B7D7-10 及び B7D7-12 の 3 ケースについてはピーク荷重, ピーク荷重が見られない 他の実験ケースでは荷重〜沈下曲線の載荷初期の部 分と載荷後半部の交点での荷重に, それぞれ根入れ部 の基礎の自重を加えた值と定義した. このようにして求 めた極限支持力と基礎の根入れ基礎幅比 $\left(D_{f} / B\right)$ との関 係を図一にに示した.

まず, 基礎幅が $5 \mathrm{~cm}$ の実験ケース(○印)に着目する と, 極限支持力は根入れ基礎幅比の增加にともないほ ぼ直線的に増していることが分かる. また, 基礎幅が $7 \mathrm{~cm}$ の場合を見ると, 本研究では $D_{f} / B$ が 1 の場合しか 行っていないが, 基礎幅が $5 \mathrm{~cm}$ の場合の支持力に比べ て約 1.4 倍大きな支持力を示していることが分かる.

\section{c）地盤の変形挙動}

鈶直載荷による地盤の変形挙動を観察するために, いくつかの実験ケースでは粘土地盤前面にターゲットを 約 $2 \mathrm{~cm}$ 間隔で設置した. 実験ケース B7D7-10 で得られ た地盤の変形挙動を図一に示す. 図中, 模型基礎を矩 形で囲って示している. また, 図には鈶直載荷の開始か ら極限支持力に達した時点までの各ターゲットの変位

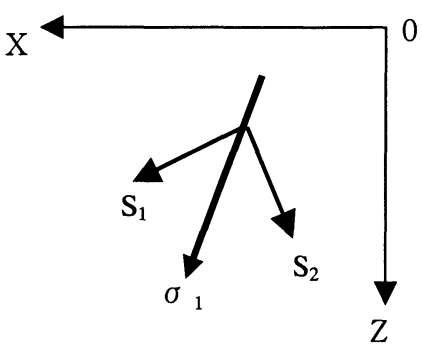

図-7 特性曲線

ベクトルを, 変位の大きさを実際の変位量の 5 倍に拡大 して示している.

図より, 基礎直下のターゲットが基礎の沈下に伴いほ ぼ鉛直下方向に大きく変位していることが分かる.この ケースでは, 鉛直載荷の開始から荷重が極限荷重に達 するまでに基礎が約 $0.5 \mathrm{~cm}$ 沈下しているため, 基礎直 下のターゲットも同様に変位したものと思われる. 一方, 基礎直下以外の部分での変位は全般的に小さいことが 分かる. ベクトルの向きについて見ると, 基礎端部付近 では水平方向の変位が卓越しているが, その他の部分 では水平方向ないしは斜め上方向に大きく変位してい る傾向が見られる. また, 基礎側面付近では基礎に引き ずり込まれることなく, ほとんど変位していないことが分 かる.

\section{4. 特性曲線法による解析と実験結果との比較}

\section{（1）計算と結果の表記}

特性曲線法による解析は, 2. に述べた研究例以外 にも多く行われており, 式展開も詳しく述べられている. そこで, 紙数の制約もあるため,ここでは簡潔に説明す るに留める.

まず, 二次元基礎に関する地盤中の力のつり合い方 程式は次式で与えられる.

$$
\begin{aligned}
& \frac{\partial \sigma_{x}}{\partial x}+\frac{\partial \tau_{x z}}{\partial z}=0 \\
& \frac{\partial \tau_{x z}}{\partial x}+\frac{\partial \sigma_{z}}{\partial z}=\gamma^{\prime}
\end{aligned}
$$

ここに, $\sigma_{x}, \sigma_{z}, \tau_{x z}$ はそれぞれ水平方向と鈶直方向 の直応力, せん断応力であり, $\gamma$ '地盤の有効単位体 積重量である. 次に, 破壊規準として次式に示すモ一 ル・クーロンの規準を適用した.

$$
\sigma_{1}-\sigma_{3}=2 c^{\prime} \cos \phi^{\prime}+2 \sigma_{m}{ }^{\prime} \sin \phi^{\prime}
$$




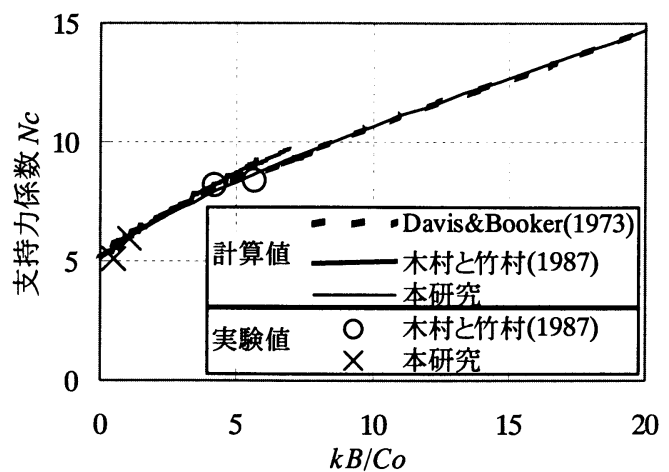

図-8 支持力係数 $\sim k B / C_{0}$ （表面基礎）

ここに, $\sigma_{1}, \sigma_{3}, \sigma_{m}$ はそれぞれ最大・最小主応力, 平均主応力である. また, $c^{\prime}$ と $\phi^{\prime}$ は地盤の粘着力と内 部摩擦角をそれぞれ表している.

式(1)ならびに式(2)を展開して求められるすべり線は, 図-7 に示すように最大主応力 $\left(\sigma_{1}\right)$ の向きに対して $\pm\left(\pi / 4-\phi^{\prime} / 2\right)$ の角度に 2 方向発生する. 今回の計 算では, 地盤表面から計算を進め, 基礎側面ならびに 底面での境界条件を満たすまで繰り返し計算を行った. また, 基礎の支持力は底面での応力条件から鉛直成分 を計算し, それを合計して求めた.

本研究では, 計算結果を正規化して表記するため, 下記に示す Terzaghi の支持力公式を援用した支持力 係数を用いることとした.

$$
q=c N_{c}+\gamma_{1} D_{f} N_{q}+\gamma_{2} \frac{B}{2} N_{\gamma}
$$

ここに $N_{c}, N_{q}, N_{\gamma}$ は支持力係数, $\gamma_{1}, \gamma_{2}$ はそれぞれ根 入れ部分之基礎底面下の土の単位体積重量, $D_{f}$ は根 入れ深さ, $B$ は基礎幅をそれぞれ示している. 今回の研 究は $\phi^{\prime}=0$ 材を対象としているので $N_{q}=1, N_{\gamma}=0$ であ り, 式(3)は下式のように表される.

$$
q=c N_{c}+\gamma_{1} D_{f}
$$

地盤強度の深度分布の影響について, 各支持力係数 に影響係数を付加して表記する方法と支持力係数自体 に含めて表記する方法がある. Davis and Booker $\left.{ }^{4}\right)$ は 前者の表記法で, Tani and Craig ${ }^{6}$ は後者の表記法を 用いている.ここでは後者の方法で表記することとする.

\section{（2）表面基礎に関する計算結果}

今回の計算結果の正確さを既存の解析および実験 結果と照査するため, まず表面基礎の支持力について, 地盤の強度条件を変えながら計算を行った. 基礎底面 の粗さは, 実験条件にあわせて完全にスムースな条件 しした. 得られた計算結果を図-8 に示す. 図中の縦軸 は計算で得られた支持力值から式(4)により求められた

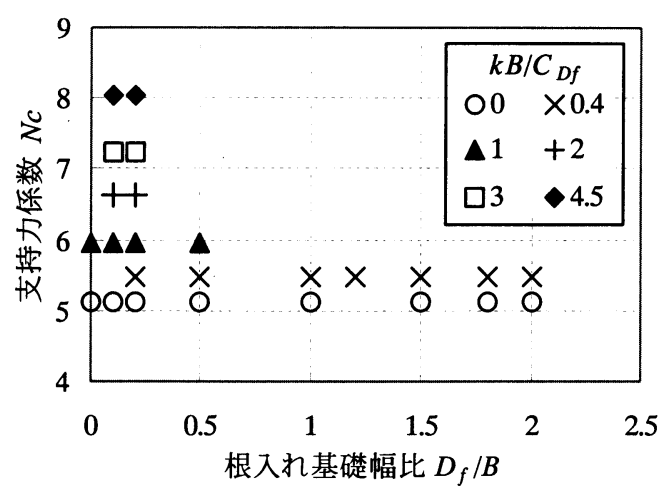

図-9 支持力係数 $D_{f} / B$ （根入れ基礎）

支持力係数 $N_{c}$ を, 横軸は $k B / C_{0}$ をそれぞれ示している. なお, $C_{0}$ は基礎底面でのせん断強度, $k$ は深さ方向の 強度増加率, $B$ は基礎幅をそれぞれ示す。

図より, 支持力係数 $N_{c}$ は $k B / C_{0}$ の増加に伴いほぼ一 様に增加する傾向が見られる. 図には, Davis and Booker ${ }^{4)}$, 木村と竹村 ${ }^{5)}$ による計算結果もあわせてプロ ットした. Davis and Booker の計算は今回の計算と同じ 特性曲線法によるものであり, 今回の計算結果とほぼ完 全に一致していることが分かる. また, 木村と竹村による 上界定理による計算結果と比較すると, 本研究の計算 結果は若干小さめであるが, 比較的良い一致を示して いることが分かる.

また図には, 木村と竹村 ${ }^{5)}$ にるる実験值 (図中の○ 印)と本実験結果 (B5D0とB10D0) (図中の×印)もあわ せてプロットした. 木村と竹村による実験值は, 本研究と は異なる粘土を用いて行った遠心場での支持力実験 結果である. 計算結果はいずれの実験結果ともほぼ一 致していることが分かる.

\section{（3）根入れ基礎に関する計算結果 a）地盤の自重がない場合}

次に, 地盤強度が深度方向に増加する地盤で根入 れがある基礎について計算を行った. 基礎の底面, 側 面はいずれもスムースの条件である. 計算上のパラメー 夕として, $k B / C_{D f}\left(\right.$ 根入れ深さ $D_{f}$ である基礎底面でのせ ん断強度という意味で $C_{D f}$ と表記する)に加え, 根入れ 基礎幅比 $D_{f} / B$ がある.

計算は地盤の強度分布と基礎の根入れ深さを種々に 変化させることで, $k B / C_{D f}$ を変化させて行った. 図一 9 に は地盤の自重がない場合の計算結果を縦軸に支持力 係数 $N_{c}$, 横軸に根入れ基礎幅比 $\left(D_{f} / B\right)$ で示した. ここ で支持力係数 $N_{c}$ は, 計算で得られた支持力値 $(Q)$ を基 礎の底面位置での地盤強度 $\left(C_{D f}\right)$ で除して求めたもの である. 図-9ではそれぞれの $k B / C_{D f}$ ごとにマークを変え て示している. 計算結果は $k B / C_{D f}$ の值によって異なる支 


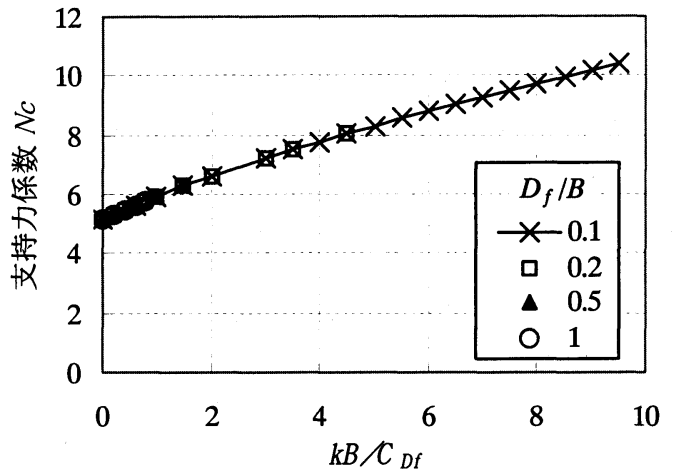

図-10 支持力係数 $k B / C_{D f}$ (自重なし)

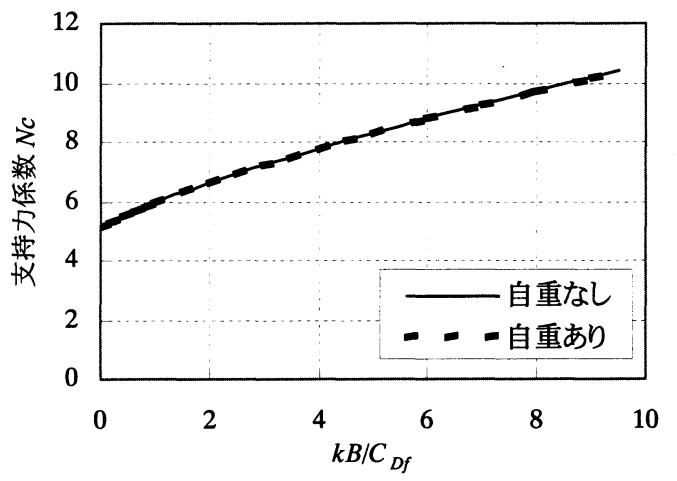

図-11 支持力係数 $\sim k B / C_{D f}$ (自重あり)

持力係数を示しているが, 同じ $k B / C_{D f}$ の場合には支持 力係数は根入れ基礎幅比に関係なく一定であることが 分かる.なお, 比較的大きい $k B / C_{D f}$ の場合には $D_{f} / B$ の 比較的小さい場合のみしかプロットされていない.これ は, 根入れ基礎幅比と地盤の強度増加率が大きく地盤 表面でのせん断強度 $C_{0}$ が負の值になる場合には計算 を行わなかったためである.

図-10 は, 図-9 に示した計算結果について $k B / C_{D f}$ を 横軸にプロットし直したものである. 図より，地盤の $k B / C_{D f}$ が増加するにつれ支持力係数がほぼ一様に増 加する傾向が見られる. また, 基礎の根入れ基礎幅比 が異なっても, 支持力係数 $N_{c}$ は一本の線上にプロットさ れており, 基礎の根入れには影響されないことが確認で きた.

\section{b）地盤の自重がある場合}

次に, 地盤の自重がある場合について計算を行った。 計算では, $D_{f} / B$ の大きさを $0.1 \sim 1$ まで変化させて計算 を行い, 図-11 に支持力係数 $N_{c}$ と $k B / C_{D f}$ との関係を示 した.なお, 図には自重なし場合の計算結果 (図-10)も あわせて示した. 図より, 地盤の自重がある場合の $N_{c}$ と $k B / C_{D f}$ の関係は, 当然ながら自重のない場合と一致す る計算結果を得ることを確認した。

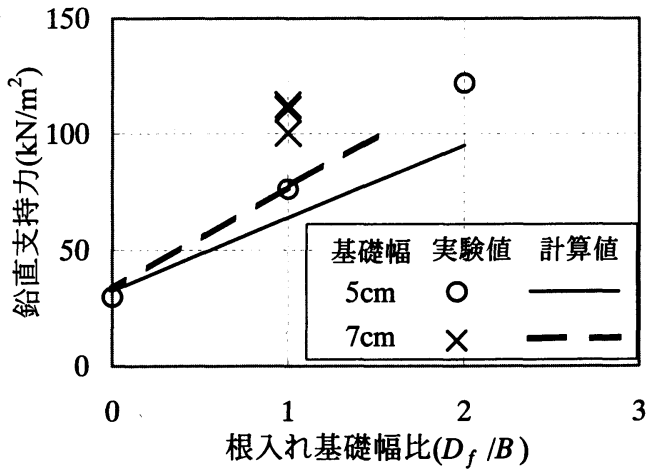

図-12 実験値之計算值の比較 (支持力 $D_{f} / B$ )

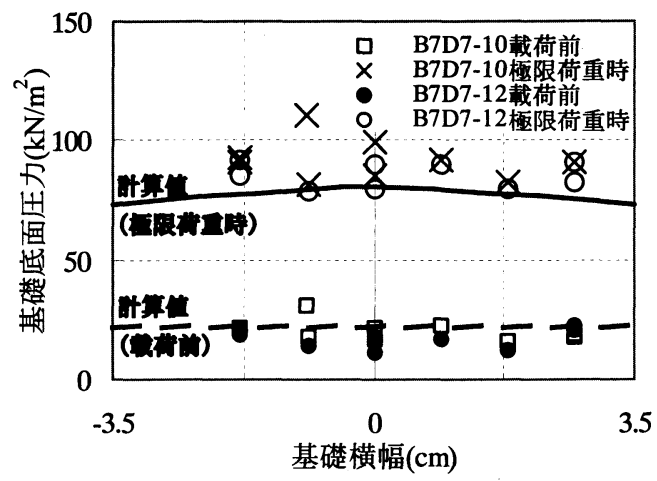

図-13 実験値之計算値の比較 (基礎底面圧力分布)

\section{(4) 実験結果との関係}

\section{a) 支持力〜根入れ深さ関係}

次に実験の地盤条件をあわせて計算を行い, 鈶直支 持力と根入れ基礎幅比との関係を図-12 に示した. 図 には図一 に示した実験値もあわせて示している. 図より, 基礎の根入れのない場合には, 計算值と実験值はほぼ 一致している. 一方, 根入れ基礎幅比が大きくなると実 験值は計算値より $20 \%$ 程度大きいことが分かる. この傾 向は基礎幅の大きさによらず見られた.この理由として， 実験では基礎側面の根入れ部分及び底面に潤滑剤を 塗布して粘着力の除去に努めたものの, 完全ではなか ったこと等が考えられるが，その詳細は分かっていない． これに関しては今後の検討課題ししたい。

\section{b) 基礎底面での反力分布}

実験ケースのうち基礎幅 $7 \mathrm{~cm}$, 根入れ $7 \mathrm{~cm} の 2$ ケー ス(B7D7-10 とB7D7-12)は, 模型基礎底面に小型の圧 力計を埋設して底面での圧力分布を計測した. 図-13 には, 実験ケース B7D7-10 及び B7D7-12 について極 限荷重時の基礎底面での圧力分布之, 解析による圧力 分布を示した. 計算値は基礎中央部で多少大きな圧力 を, 基礎端部で多少小さい圧力を示している. 実験値 には実験ケースごとに多少ばらつきが見られているが, 平均すれば計算值に対し $10 \%$ 程度大きい值を示して 
いる. 一方, 図-14 にあわせて示した鉛直載荷前の圧 力分布は測定值の方が計算值より若干小さめの值を示 しており, 鉛直載荷による圧力の増分は, 実験值が計 算值に比べて約 20\%程度大きな值を示した.

\section{5. 結論}

本研究では, 深度方向に強度の増加する地盤中の 根入れのある基礎の鉛直支持力を遠心模型実験と特 性曲線法による数值計算で検討した. 一連の研究より 得られた結論を以下にまとめる.

1)遠心模型実験より, 極限支持力は根入れ深さとともに 直線的に増加すること, 載荷後半部での鈶直応力〜 変位関係は根入れ染さに関係なくほぼ1本の線上に 乗ることが分かった.

2)特性曲線法による計算では, 支持力係数 $N_{c}$ は $k B / C_{D f}$ が大きいほど大きく, 両者の関係は地盤の単位体積 重量や根入れ基礎幅比に関係なく一定であることが 確認できた.

3)鈶直支持力の実験值と計算值とでは実験値の方が約 $20 \%$ 大きいが, 両者とも根入れ基礎幅比の増加に対 して直線的に支持力が増加する傾向が見られた。

\section{参考文献}

1) 運輸省港湾局: 港湾の施設の技術上の基準・同解説 （上)，日本港湾協会, pp.525-536, 1999.

2) 北詰昌樹: 深層混合処理工法による改良地盤の安定性 に関する研究, 港湾技術研究所資料, No.774, 1994.

3) Kusakabe, O. and Lee, M. W. : Development of bearing capacity studies and changing foundation design, Eleventh
Asian Regional Conference on Soil Mechanics and Geotechnical Engineering, Vol.2, pp.729-751, 2001.

4) Davis, E. H. and Booker, J. R.: The effect of increasing strength with depth on the bearing capacity of clays, Geotechnique, Vol.23, No.4, pp.551-563, 1973.

5) 木村 孟, 竹村次朗: 帯基礎による正規圧密粘性土地盤 の変形・支持力に関する研究, 土木学会論文集, No. 382/III -7, pp.157-166, 1987.

6) Tani, K. and Craig, W. H. : Bearing capacity of circular foundations on soft clay of strength increasing with depth, Soils and Foundations, Vol. 35, No.4, pp.21-35, 1995.

7) Martin, C. M. : Vertical bearing capacity of skirted circular foundations on tresca soil, Proceedings of the $15^{\text {th }}$ international conference on soil mechanics and geotechnical engineering, Vol.1, pp.743-746, 2001.

8) 西村 学, 末政直晃, 斉藤邦夫, 中瀬明男: 過圧密地盤 における根入れを有する基礎の支持力特性に関する研 究, 第 23 回土質工学研究発表会, pp.1305-1308, 1988.

9) 飯島興二, 末政直晃, 竹村次朗, 木村 孟:粘性土地盤 における根入れのある基礎の支持力特性, 第 22 回土質 工学研究発表会, pp.1079-1080, 1987.

10) 北詰昌樹, 遠藤敏雄, 寺師昌明:正規圧密地盤上の浅 い基礎の支持力, 港湾技術研究所報告, Vol.27, No.3, pp185-203, 1988.

11）石鍋仁史, 森本弘光, 小林利雄, 片上典久, 斎藤邦夫: 中間的な根入れを有する基礎の支持力特性, 第 32 回地 盤工学研究発表会, pp.1405-1406, 1997.

(2002.1.7 受付)

\title{
CENTRIFUGE MODEL TESTS AND ANALYSES ON VERTICAL BEARING CAPACITY OF EMBEDDED FOUNDATION
}

\author{
Masaki KITAZUME and Takeshi NAKAMURA
}

\begin{abstract}
A series of centrifuge model tests and numerical analyses were carried out to investigate vertical bearing capacity of embedded foundation in a clay ground whose undrained shear strength increases with depth. The embedded depth and the width of the foundation are changed in the model tests to study these effects on the bearing capacity. It is found that the bearing capacity increases almost linearly with increasing the ratio of embedded depth and width of the foun-dation. A series of stress characteristic analyses was also carried out to investigate the effects of ground strength dis-tribution with the depth, and ratio of the embedded depth and width of the foundation on the bearing capacity. It was found that the measured vertical bearing capacities were well coincided with those of calculation.
\end{abstract}

